\title{
Efficiency of Foreign Banks Operating in India:
}

\section{DEA Analysis}

\author{
Dr Namita Rajput \\ Associate Professor, Sri Aurobindo College, University of Delhi \\ E-mail: Namitarajput27@gmail.com \\ Kamna Chopra (Corresponding author) \\ Assistant Professor, Sri Aurobindo College, University of Delhi \\ E-mail:kamnachopra31@yahoo.com
}

Shelly Oberoi

Research Scholar, Annamalai University

E-mail: Shellyoberoi83@gmail.com

Received: May 6, 2014 Accepted: July 27, 2014 Published: December 1, 2014

doi:10.5296/ajfa.v6i2.5591 URL: http://dx.doi.org/10.5296/ajfa.v6i2.5591

\begin{abstract}
Indian financial sector has observed various modifications in the policies and prudential norms to raise the banking standards in India to the international strength. Various financial reforms have taken place in 1991 which improved flexibility and operational autonomy in the banking sector. In 1992, on the recommendation of Narasimham committee, a series of developments were instigated. In 1993-94, the approval was accepted for the entry of new private banks and foreign banks in Indian banking sector. After the post reform era, the operations of Foreign Banks (FBs) received a considerable boost. The Reserve Bank of India liberalized its policy for foreign banks implying new opportunities for growth and different representations in India. The present study makes an attempt to measure and compare the efficiency scores of Public Sector Banks (PSBs), Private Sector banks and FBs operating in India during 2008-2013 using frontier based non-parametric technique, i.e., DEA, the result demonstrates that the efficiency of FBs has shown continuous improvement in comparison with PSBs and Private Banks following the route of deregulation with modest drifts.
\end{abstract}

Keywords: DEA, Efficiency, Foreign Banks, Indian financial sector, NPAs 


\section{Introduction}

Indian financial sector has incessantly faced the rapid change in the banking system. Before reform period, Indian banking industry was neither perfect nor flexible. In order to create more diversified, efficient and elastic banking system, in 1992, Government of India (GOI) commenced inclusive banking reforms. One of the chief objectives of financial reforms was to promote flexibility, operational autonomy and to make them competitive by raising the banking standards in India to the international best practices (Reddy, 2002). Each and every facet of the banking industry, be it non-performing asset management, customer service, risk management, human resource development, etc has to undergo the process of transformation to line up with international Standards (Muniappan, 2003). The broad framework of reform plan was drafted by the Committee on the Financial System under the supervision of Narasimham (1991), whilst the explicit shape to the plan was provided by the Committee on the Banking Sector Reforms (Narasimham, 1998). Consequently, the Indian banking sector, which was principally controlled by the government, was liberalized. As an outcome, in 1993, the government allowed new private sector to enter the banking sector and additionally the foreign banks from 1994. Since then, large number of FBs showed their interest in opening their respective branches in India to gain the noteworthy benefits of liberalized regime of Indian financial system. Foreign banks have brought the newest technology and new banking practices to India which has helped the domestic banks to improve their performance and provide better customer services. Foreign banks in India captured a large customer base due to their speedy and well-organized working style and better customer service. Prior to $90 \mathrm{~s}$, foreign banks effortlessly distinguished themselves vis-a-vis public sector banks. They adopted technology to their advantage to generate and often sustain lead in premium services like integrated cash management, 24-hour phone banking, and internet banking, securitisation, Forex and interest rate derivatives trading, risk management and Know Your Customer (KYC) software solutions. For instance, the first Automated Teller Machine (ATM) in the country was set up in 1987 by HSBC. This focus on innovation helped foreign banks build gainful businesses with a reasonably high share of investment and income. In 20012-13, 43 FBs were operated in India. Top position is acquired by FBs in total number of banks in all three bank groups of Indian scheduled commercial banking system, i.e., 26 banks of public sector banks and 20 banks of private sector banks. In 2008-09, The Reserve Bank of India announced a new rule for foreign banks in India by permitting them to grow in an unfettered way as in 1997, India had committed to the World Trade Organization (WTO) to give 12 new branch licenses to foreign banks every year, including new entrants and the existing players. At present foreign banks in India are legalized to set up their local subsidiaries. After the entry of foreign banks in India, the Indian banking sector has become more competitive and proficient. In Asia Pacific zone, India is considered to be most Leading investment market due to the growth of Indian economy and the assortment of income streams and product lines which give them the sturdiness to grow(Neeraj Swaroop,2011). As of March 2013, there are 43 foreign banks from 26 countries operating as branches and 46 banks from 22 countries operating as representative offices. Standard Chartered Bank, the oldest foreign bank that came to India 150 years ago is now operating with 101 branches followed by HSBC with 50 branches. Citibank has 42 branches and ABN Amro Bank which is now known by Royal 
Bank of Scotland N.V has 24 branches. The other banks that have a double digit branch existence are Deutsche Bank (18) \& DBS Bank (12).Considering the current scenario, an assessment of performance and efficiency level is needed about the working of FBs. This paper is an attempt to offer insights with respect to functioning and profitability of FBs in India and will also plot the efficiency level in post-liberalized regime.

In the above backdrop, the focus of the paper is to compare the efficiency of the foreign owned banks with PSBs and Private Banks operating in India and also to determine how the efficiency of FBs have improved in the recent time period. The paper is organized as follows. Section 1 i.e. the present section gives the insights of Indian Banking Industry and entry of FBs in India followed by Section 2 which gives a review of the existing literature in the areas of efficiency measurement of foreign banks in the Indian context. Research objectives are exposed in Section 3. Section 4 identifies database and methodology used. Interpretation of the results and analysis of this paper are summarized in Section 5. Conclusion will be the part of Section 6. References used in the study will be a part of the last Section.

\section{Review of Literature}

Performance refers to financial performance of banks which is measured by appropriate accounting ratios, for example, the return on assets (ROA). Efficiency refers to cost efficiency, that is, the capability to produce a given level of output at the lowest cost. To construct the conceptual framework for this paper, we put light on the literature on PSBS, foreign banks and private banks. Galalet al. (1994), and La Porta and Lopezde- Silanes (1997) uphold the view that performance can be improved through privatization. However, recent studies in transition economies, for example, by Carlin and Landesman (1997), Frydman et al. (1998), and Jones and Mygind (1999) instituted that post privatization performance of the firms was poor. The RBI (2003) affirmed that "as regards the linkage between ownership and performance, international evidence suggests that ownership has limited impact on economic efficiency." Researches that hold this point include those of Tulkens (1993), Altunbus, Evans and Molynenx, (2000) and Denizer, Tarimcilar and Dinc (2000). Barr \&Siems, (1994) study scrutinize that banks are more efficient with high efficiency scores and are more competent to carry on as compare to banks which have low efficiency scores. Mohan (2005) concluded that an efficient financial system contributes to resource generation, intermediation and allocation and hence contributes to economic growth and risk mitigation process. According to Roma Mitra, Shankar Ravi (2008), for increasing the economic level of a country, a stable and efficient banking sector is a prerequisite. This study tries to represent and assess the efficiency of 50 Indian banks. The Inefficiency can be evaluated and quantified for every evaluated unit. To estimate and compare efficiency of the banking sector in India is the objective of this paper. The analysis inculcates the verification or rejection of the hypothesis whether the banking sector fulfils its intermediation function sufficiently to compete with the global players and evaluates the performance of Banking Sectors in India. The results are insightful to the financial policy planner as it identifies priority areas for different banks leading to improvement in their performance. In an evaluation of the financial performance of Indian private sector banks said that Private sector banks play a key role in development of Indian economy. The economic reforms totally have changed the banking sector. RBI 
allowed new banks to be started in the private sector as per the recommendations of Narasimham committee. There was the domination of Indian banking industry by public sector banks. But now the situations have changed new generation banks with use of technology and professional management has gained a rational position in the banking industry. Brijesh K. Saho, Anandeep Singh (2007), this paper attempts to scrutinize, the performance trends of the Indian commercial banks for the period: 1997-98 - 2004-2005. Our broad empirical findings are pinpointing in many ways. First, there is a signal of an affirmative gesture about the effect of the reform process on the performance of the Indian banking sector by the increasing average annual trends in technical efficiency for all ownership groups. Second, the higher cost efficiency accrual of private banks over nationalized banks indicate that nationalized banks, though old, do not reflect their learning experience in their cost minimizing behavior due to X-inefficiency factors arising from government ownership. This finding also highlights the possible stronger disciplining role played by the capital market indicating a strong link between market for corporate control and efficiency of private enterprise assumed by property right hypothesis. And, finally, concerning the scale elasticity behavior, the technology and market-based results differ significantly supporting the empirical distinction between returns to scale and economies of scale, often used interchangeably in the literature. Vradi, Vijay, Mauluri, Nagarjuna (2006), in his study on'" Measurement of efficiency of banks in India" concluded that in modern world performance of banking is more important to stable the economy in order to see the efficiency of Indian banks. We have seen the fore indicators i.e. profitability, productivity, assets quality and financial management for all banks such as public sector, private sector banks in India for the period 1999-2000 to 2002-2003. There is an adoption of development envelopment analysis for measuring the efficiency of banks leading to a conclusion that public sectors banks are more efficient then other banks in India. Petya Koeva (July 2003), in his study on "The Performance of Indian Banks" concluded that during Financial Liberalization period new empirical evidence has been seen due to the impact of financial liberalization on the performance of Indian commercial banks. The analysis focuses on examination of the behavior and determinants of bank intermediation costs and profitability during the liberalization period has been focused by the analysis. The empirical results suggest that ownership type has a major effect on some performance indicators and that the observed augment in competition during financial liberalization has been related with lower intermediation costs and a profitability of the Indian banks.

\section{Research Objectives}

Foreign banks have a progressive position in Indian banking system after financial reforms. In this paper, we will examine the improved performance of FBs through the efficiency measurement. The rationale of this paper is to compare the efficiency of foreign banks with PSBs and Private Banks operating in India over the study period (2008-2013). The noteworthy insights are attained by empirical exploration which could be useful for the management of Indian financial \& non-financial counterparts. This paper will offer useful information to regulators and policy makers. We can postulate the research objectives as follows: 
* To analyze the overall performance of FBs operating in India (as a group) in comparison with PSBs and Private Banks.

* To gauge the efficiency of each bank towards the elements of efficiency and overall performance.

To achieve the above objectives following empirical hypotheses are formulated:

Hypothesis 1: Efficiency of foreign banks (as a group) has improved during the recent time period from 2008-2009 to 2012-2013 in comparison with PSBs and Private Banks.

Hypothesis 2: Efficiency measures have resulted in higher efficiency level of each individual banking unit of foreign sector banks.

\section{Data and Methodology}

\subsection{Database}

The study has measured the efficiency level of all FBs operating in India during the last Eight years from 2008-2009 to 2012-2013. The focal point of the paper is to assess the efficiency scores of the banks using DEA analysis. While there are $43 \mathrm{FBs}$ that are working currently in India but due to the limitation of incomplete data of twelve banks, the paper excluded such banks from the sample. Those banks are Australia and Newzealand banking group, Commonwealth bank of Australia, Credit Suisse AG, First Rand Bank, Industrial and commercial bank of China, National Australia Bank, ReboBank International, Sber Bank, Sumitomo Mitsui Banking Corporation, United Overseas Bank, Westpac Banking Corporation, and Woori Bank. In this study, the sample size of $31 \mathrm{FBs}$ is taken which is adequately large to take care of the constrictions imposed by the requirement of the DEA model.

\subsection{Methodology}

Data Envelopment Analysis (DEA) is a non-parametric linear programming based data analysis methodology introduced by Charnes, Cooper, and Rhodes in 1978, today called the CCR model. Building on the ideas of Farrell (1957), the seminal work "Measuring the efficiency of decision making units" by Charnes et al. (1978) applies linear programming to estimate an empirical production technology frontier for the first time. Since then, there have been a large number of books and articles written on DEA or applying DEA on various sets of problems. Other than comparing efficiency across DMUs within an organization, DEA has also been used to compare efficiency across firms. There are several types of DEA with the most basic being CCR, however there are also DEA which address varying returns to scale, either CRS (constant returns to scale) or VRS (variable return to scale). The main developments of DEA in the 1970s and 1980s are documented by Seiford \& Thrall (1990).It assumes constant returns to scale and an orientation. The study suggests the fact that banks use certain inputs to produce certain outputs. Thus, the efficiency of the banks will be measured with respect to how efficiently they are able to utilize their inputs. Efficiency is measured by the ratio of weighted outputs to weighted inputs. The study suggests the fact that banks use certain inputs to produce certain outputs. The ratio has the following form: 
$u 1 y 1+u 2 y 2+\ldots \ldots . u n y n$,

$v 1 x 1+v 2 x 2+\ldots \ldots v n x n$

Where $u, v$ are the weights for the outputs,

$(y 1 \ldots y n)$ and inputs $x(x 1 \ldots \ldots . . . x n)$, respectively

Assume that for each of the $N$ firms there are data on $K$ inputs and $M$ outputs and represented by the column vectors $x i$ and $y i$ respectively for the $i$ th firm. This may be expressed as ( $u^{\prime} y i$ ) $v^{\prime} x i$ ), where $u$ is an $M X 1$ vector of output weights and $v$ is a $K X 1$ vector of input weights. To arrive at the optimal weights, we define the following linear programming problem as:

$\operatorname{Max} u, v\left(u^{\prime} y i / v^{\prime} x j\right),(1)$

Subject to

$u^{\prime} y j / v^{\prime} x j \quad 1, j=1,2 \ldots n$,

$u, v \quad 0(1)$

Solving (1) will involve finding values for $u$ and $v$ such that the efficiency measure for each firm is maximized. A notable difficulty with this particular model formulation is that it can have an infinite number of solutions. Thus, an additional constraint is added, $v^{\prime} x i=1$ so that this problem can be avoided. The new model, known as the transformation model, thus becomes:

$\operatorname{Max}, v(\quad y i),(2)$

Subject to, $v^{\prime} x i=1$

$$
' y j-v^{\prime} x j \quad 0, j=1,2 \ldots \mathrm{N},
$$$$
\text { , } v \quad 0(2)
$$

To reflect the transformation, $u$ has been replaced by and $v$ has been replaced by $v$. This form in equation (2) is known as the multiplier form of the DEA linear programming problem. Using duality in linear programming, one can derive an equivalent envelopment form of this problem:

$\operatorname{Min}, \quad,(3)$

Subject to, $-y i+Y \quad 0$

$$
X i-X \quad 0(3)
$$

0 , where is a scalar and is a $N X 1$ vector of constants

The value obtained for will be the efficiency for the $j t h$ Decision Making Unit (DMU). The linear programming problem would be solved for each DMU taken in the study. = 1 will identify the technically efficient DMU and all other DMUs would have $<1$, implying that the efficiency scores of all other DMU will be measured relative to the technically efficient units that have a score of $=1$. In this study each bank under observation will be treated as a 
DMU. A separate frontier will emphasize the changes taking place in the macro economy and the supervisory policies of RBI. DEA gives us the relative efficiency measure of the DMUs. DEA results are sampled specific. They don't reflect the absolute efficiency measures. This means that the best performing DMU out of the group will be shown as 100 percent efficient. The rest of the DMUs will be benchmarked against this one. Another expressing way of this is to say that an efficient unit doesn't necessarily produce the maximum output viable for a given level of input (Miller \& Noulas, 1996). In this paper, we have taken an intermediation approach. Hence, deposits, investments, operating expenses and number of employees are used as inputs whereas return on assets (ROA), interest income and non-interest income together as Net Profits are taken as outputs.

\section{Interpretation of Results}

Hypothesis 1: Efficiency of foreign banks (as a group) has improved during the recent time period from 2005-2006 to 2009-2013 in comparison with PSBs and Private Banks.

Foreign banks showed an increasing pattern of efficiency as it is shown in graph (see Figure 1 and Figure 2), i.e., DEA efficiency score and Net Profits and Return on Assets (ROA) with respective figures. In 2008-09, DEA efficiency score of FBs was 1, and then it showed a slight dip in the DEA scores 2009-2010. Then in 2010-2011 FBs had 100\% efficiency level as the score was 1 but in 2011-2012, it showed a declining trend in efficiency scores, it was 0.93. The sudden dip in the efficiency scores was mainly due to the global financial crisis and increase in the NPAs of the foreign banks in that year. Then in 2012-13 FBs have recovered and shown 100\% Efficiency level. On the other hand, in 2008-09, the efficiency scores of public sector banks was 0.97 , and after that it showed a continuous downward trend till 2010-11. After 2010-2011, public sector banks had 100\% efficiency. This was mainly due to the radial changes in accounting, deregulation of interest rates, close follow-up of non-performing assets, introduction of prudential norms, voluntary retirement of old generation staff, concern for customer care as a part of reform process have made the management of PSBs to generate surpluses and make them self-sufficient. With these developments and advanced information technology in the PSBs has geared up to achieve the performance.Similar trend is seen in Private Banks as of PSBs, in 2009-10 and 2010-11, the efficiency scores of private banks have shown a declining trend. In 2011-12 and 2012-13, the efficiency score of private banks have increased mainly due to certain reforms. These results are consistent with findings of another study considering a temporal trend carried out by Rajput \& Gupta (2010) which reported that the efficiency of FBs increased for the study period of 2005-2010 in relation to PSBs and Private Banks, leading to a conclusion of acceptance of our hypothesis. 


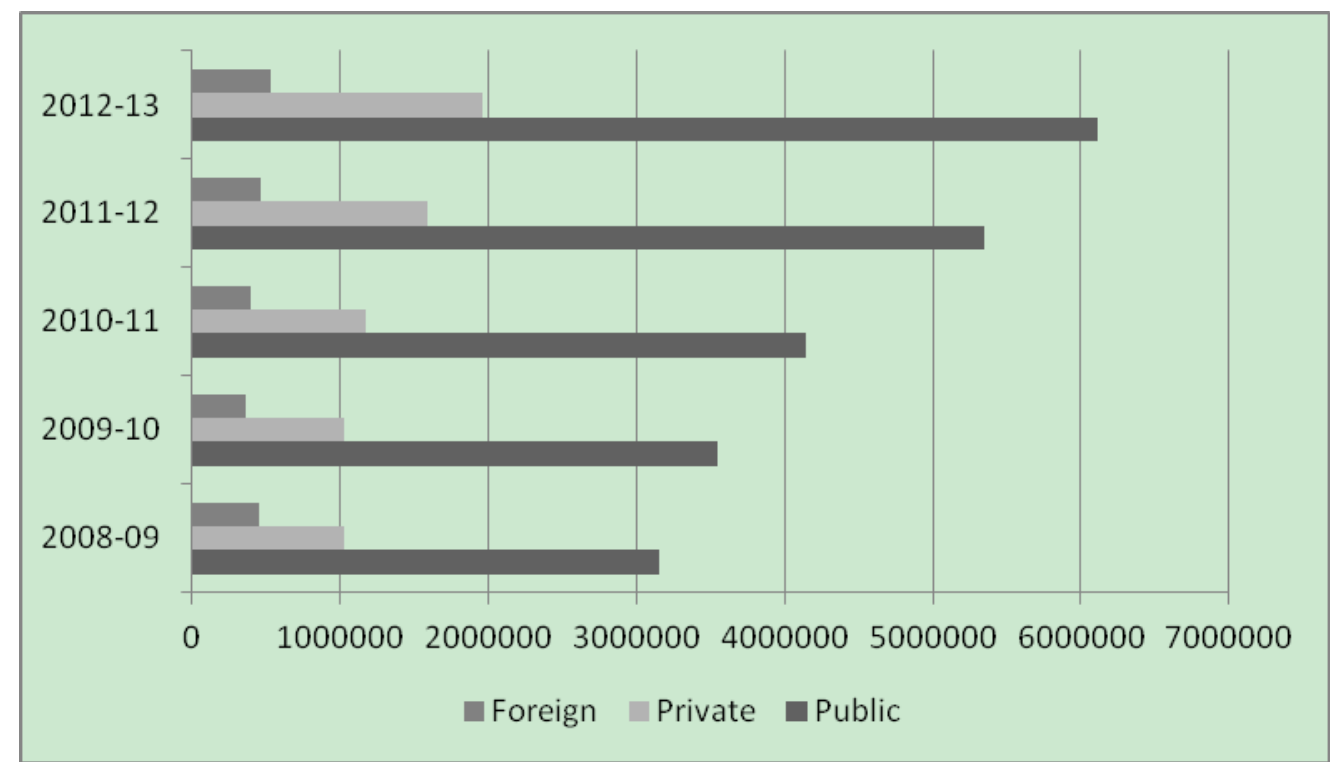

Figure 1. Trends of Net Profits of PSBs, Private Sector Banks and Foreign Banks

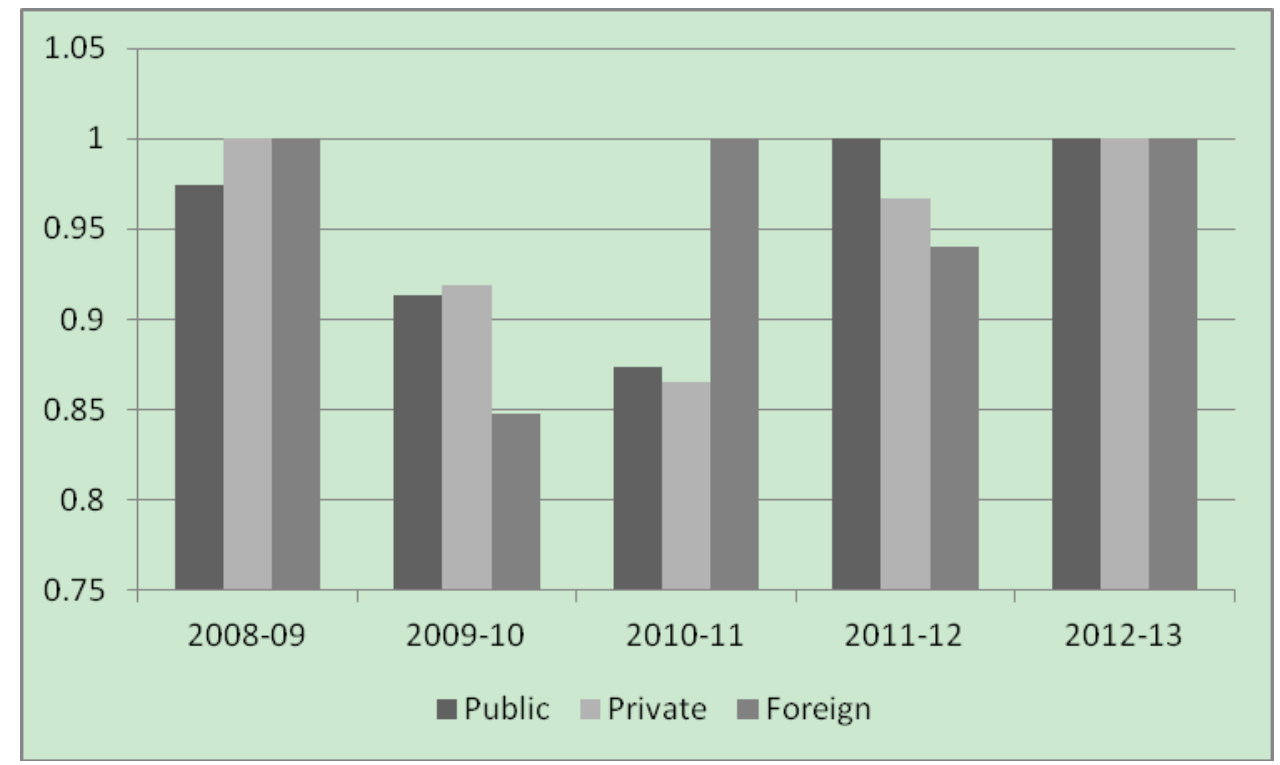

Figure 2. Trends of Efficiency Scores of PSBs, Private Sector Banks and Foreign banks

Hypothesis 2: Efficiency measures have resulted in higher efficiency level of each individual banking unit of foreign sector banks.

The analysis exhibit mixed results for individual banking unit of foreign sector banks. There are four banks (Bank Internasional Indonesia, Bank of Nova Scotia, Credit Agricol Bank and Krung Thai Bank) which are 100\% efficient throughout the assessment years (Table I \& II). Antwerp bank verified the highest efficiency level, 1, in all the years with only a fluctuation in 2010-2011. Three banks (JP Morgan bank, JSC VTB bank and Mashreq bank) exhibit $100 \%$ efficiency except in the year 2011-12.In 2012-13, out of 31 foreign banks 9 banks are 
$100 \%$ efficient. The number of efficient foreign banks has increased over the assessment years, 7 out of $31 \mathrm{FBs}$ confirmed the escalating level of efficiency. Hence, our hypothesis is accepted for 9 foreign banks which showed increasing trend in the efficiency and rejected in remaining 22 banks with the inverse picture exhibited in the results.

\section{Summary and Conclusion}

With India rising as a major Information Technology service provider in the 21 st century, many global banks have entered in India; primarily to take advantage of the low-cost technology and Available Manpower. Some foreign banks also created centres of excellence that provided services at the higher end of the value chain. Foreign banks have made substantial contribution to the Indian banking sector over the years by bringing capital and global best practices as well as grooming talent. Foreign banks has shown an increasing trend of efficiency through their efficient working style and better customer service except in 2009-10 which was mainly due to the global Financial crisis. Over the last five years, there is persistent increase in the Net profits of PSBs and Private Banks in comparison with foreign banks but as far as Efficiency scores are concerned foreign banks has shown substantial improvement. Indian banks need to improve their technological orientation, to continue their efforts to reduce the percentage of NPAs in order to augment their profitable efficiency in the near future. At the same time, they should stay in the game for impending acquisition opportunities as and when they appear in the near term. Our result exhibits that in case of foreign banks the efficiency has been tremendous and consistent throughout the period of study, especially four foreign banks .i.e. Bank Internasional Indonesia, Credit Agricol bank, Krung Thai Bank and Nova Scotia bank. The foreign banks have dominated the list of the highly efficient banks as compared to all scheduled commercial banks. Participation of foreign banks in the growth curve of the Indian economy in future years will provide foreign banks a launch pad for greater business expansion.

\section{References}

Altunbus, Y, Evans, L and Molyneux, P. (2000). Bank Ownership and Efficiency. Journal of Money, Credit and Banking, 33(4), 926-954. http://dx.doi.org/10.2307/2673929

Annual Report. (2003). Reserve Bank of India, Mumbai.

Barr \& Siems. (1994). Forecasting Bank Failure: A Non-Parametric Approach. Recherches Economiques de Louvain, 60, 411-29

Carlin, W and Landesmann, M. (1997). From Theory into Practice? Restructuring and Dynamism in Transition Economies. Oxford Review of Economic Policy, 13(2), 77-89.

Denizer, C, Tarimcilar, M and Dinc, M. (2000). Measuring Banking Efficiency in the Pre-and Post-Liberalization Environment: Evidence from the Turkish Banking System. World Bank Policy Research Paper, No 2476.

Frydman, R; Gray, C, Hessel, M and Rapaczynski, A. (1998). When Does Privatization Work? The Impact of Private Ownership on Corporate Performance in the Transition Economies. 
Economic Research Reports, 98-32, New York: CV Starr Centre for Applied Economics, New York University.

Galal, A. Jones, L, Tandon, P and Vogelsang, I (1994).Welfare Consequences of Selling Public Enterprises: An Empirical Analysis, Oxford, UK: Oxford University Press. Gazette of India-Extraordinary Notification, Part II, Sec 3 (ii) (1991 and 1997). Committee on Banking Sector Reform, Narasimham Committee, Ministry of Finance, Government of India.

Jones, Derek C and Mygind, Niels (1999). The Nature and Determinants of Ownership Changes after Privatization: Evidence from Estonia. Journal of Comparative Economics, 27, 422-441. http://dx.doi.org/10.1006/jcec.1999.1604

La Porta, R and Lopez-de-Silanes, F (1997). The Benefits of Privatization-Evidence from Mexico. Viewpoint 117, Washington, DC: World Bank.

Mohan (2005). India's experience with financial sector development. In: Basu P (ed) India's Financial Sector: Recent Reforms, Future Challenges, Macmillan India Ltd., New Delhi

Muniappan (2003). Management Challenges in Banking. Address at the NIBM Annual Day, January 6.

Narasimham, M. (1991). Report of the Committee on the Financial System, Government of India

Narasimham, M. (1998). Report of the Committee on Banking Sector Reforms, Government of India.

Neeraj Swaroop (2011). Stan Chart's regional chief executive for India and South Asia, RBI.

Rajput \& Gupta (2010). Efficiency, Productivity and Soundness of the Banking Sector in India: Data Envelopment Analysis. BVIMR, Management Edge, December issue 2011.

Reddy (2002). RBI and banking sector reforms. Reserve Bank of India Monthly Bulletin (December), 99-1008.

Roma Mitra Debnath, Ravi Shankar (2008). Measuring performance of Indian banks: an application Data Envelopment Analysis.

Sahoo et al. (2007). Productive performance evaluation of the banking sector in India using data envelopment analysis. International Journal of Operations Research, 4(2), 63-79.

Tulkens, H (1993). On FDH Efficiency Analysis: Some Methodological Issues and Applications to Retail Banking. Journal of Productivity Analysis, 4(1), 183-210. http://dx.doi.org/10.1007/BF01073473 


\section{Appendix}

Table I: Net Profits and Efficiency scores of foreign banks (as a group)

\begin{tabular}{|c|c|c|}
\hline YEAR & Net Profits & Efficiency Scores \\
\hline $2008-09$ & 452160 & 1 \\
\hline $2009-10$ & 363410 & 1 \\
\hline $2010-11$ & 395049 & 0.847199824 \\
\hline $2011-12$ & 468925 & 1 \\
\hline $2012-13$ & 534613 & 0.939770526 \\
\hline
\end{tabular}

Source: RBI publication, a profile of banks

Table II. DEA Efficiency scores of foreign banks (Individual)

\begin{tabular}{|c|c|c|c|c|c|c|}
\hline No & Name of the Bank & 2008-09 & 2009-10 & 2010-11 & 2011-12 & 2012-13 \\
\hline 1 & $\mathrm{AB}$ bank & 1 & 1 & 0.601172 & 1 & 0.699619 \\
\hline 2 & Abu Dhabi bank & 0.458207 & 0.496351 & 0.54963 & 0.720938 & 0.951938 \\
\hline 3 & American express & 0.773916 & 0.902884 & 0.439515 & 0.751628 & 1 \\
\hline 4 & Antwerp diamond bank & 1 & 1 & 0.857509 & 1 & 1 \\
\hline 5 & Bank Internasional Indonesia & 1 & 1 & 1 & 1 & 1 \\
\hline 6 & Bank of America & 0.651736 & 0.82944 & 1 & 0.782573 & 0.948063 \\
\hline 7 & Bank of Bahrain and Kuwait & 0.280476 & 0.629936 & 0.527522 & 0.63218 & 0.699172 \\
\hline 8 & Bank of Ceylon & 1 & 0.796349 & 0.777925 & 0.997031 & 0.937036 \\
\hline 9 & Bank of Nova Scotia & 1 & 1 & 1 & 1 & 1 \\
\hline 10 & Bank of Tokyo and Mitsubishi & 0.873156 & 0.553055 & 1 & 0.761446 & 0.802786 \\
\hline 11 & Barclays bank & 0.478877 & 0.695733 & 0.755045 & 0.425205 & 0.775214 \\
\hline 12 & BNP Paribas & 0.576987 & 0.793923 & 0.829472 & 0.659577 & 0.866426 \\
\hline 13 & China Trust Commercial bank & 0.782612 & 1 & 0.626425 & 0.904947 & 0.492183 \\
\hline 14 & Citibank & 0.502283 & 0.812547 & 0.714478 & 1 & 0.615562 \\
\hline 15 & Credit Agricol & 1 & 1 & 1 & 1 & 1 \\
\hline 16 & DBS bank & 0.651035 & 0.682199 & 0.565053 & 0.594942 & 0.68051 \\
\hline 17 & deutsche bank & 0.475781 & 0.801458 & 0.852679 & 0.746494 & 0.70769 \\
\hline
\end{tabular}




\begin{tabular}{|c|c|c|c|c|c|c|}
\hline 18 & Hongkong and Shanghai bank & 0.472976 & 0.579553 & 0.535199 & 0.466043 & 0.498516 \\
\hline 19 & HSBS bank Oman & 0.290802 & 0.661437 & 0.569308 & 1 & 1 \\
\hline 20 & JP Morgan chase bank & 1 & 0.358754 & 1 & 0.975539 & 1 \\
\hline 21 & JSC VTB bank & 1 & 0.788584 & 1 & 0.883756 & 1 \\
\hline 22 & Krung Thai bank & 1 & 1 & 1 & 1 & 1 \\
\hline 23 & Mashreq bank & 0.735466 & 1 & 1 & 0.940777 & 0.891328 \\
\hline 24 & Mizuho Corporation bank & 0.475165 & 0.713082 & 0.958932 & 1 & 0.52036 \\
\hline 25 & Royal bank of Scotland & 0.548023 & 0.842036 & 0.650288 & 0.569072 & 0.89409 \\
\hline 26 & Shinhan bank & 0.544028 & 1 & 0.895405 & 1 & 1 \\
\hline 27 & Societe Generale & 0.493528 & 0.351455 & 0.630969 & 0.550888 & 0.693161 \\
\hline 29 & Sonali bank & 0.597904 & 0.527954 & 0.26438 & 0.797799 & 1 \\
\hline 30 & Standard Chartered bank & 0.509163 & 0.939145 & 0.716881 & 0.674554 & 0.699164 \\
\hline
\end{tabular}

Source: RBI publication, a profile of banks 